\title{
Constraints in Production, Marketing and Processing of Onion (Allium Cepa L.) in Nuh District of Haryana
}

\author{
Raj Kumar ${ }^{1 *}$, Dalip Kumar Bishnoi ${ }^{2}$, Sumit $^{3}$ and Ajay Singh ${ }^{1}$
}

${ }^{1}$ Senior Research Fellow, Directorate of Human Resource Management, CCS Haryana Agricultural University Hisar, Haryana, India ${ }^{2}$ Assistant Scientist, Department of Agricultural Economics, CCS Haryana Agricultural University Hisar, Haryana, India ${ }^{3}$ Assistant Professor, Agricultural Economics, CoA, Kaul, India

*Corresponding author: rajkumarkashyap301@gmail.com (ORCID ID: 0000-0003-3089-6234)

Received: $22-08-2020$

Revised: $24-11-2020$

Accepted: 09-12-2020

\begin{abstract}
Onion (Allium cepa L.) is one of the important commercial vegetable crops grown in India. The present study was conducted in Nuh district of Haryana on the basis of highest production of onion among other districts of the state. The block named Tauru was selected for sampling and a total of thirty onion farmers from various villages in this block were selected randomly. The primary data for the agriculture year 2017-18 were collected by personal interviews of the selected farmers with the help of specially designed schedule. The results of the study revealed that the major problems faced by the onion farmers in production were observed high cost of pesticide $(93.33 \%)$, lack of knowledge about recommended fertilizer doses $(86.67 \%)$, high cost of fertilizer (83.33\%), lack of knowledge about the control measures for various pests and diseases (83.33\%), difficulty in identifying the pests and diseases $(80.00 \%)$ and lack of knowledge about seed/seedling treatment (76.67\%). As for as marketing of onion is concerned, 83.33 per cent of respondents opined that high cost of transportation, absence of minimum support prices $(83.33 \%)$, existence of large number of intermediaries in marketing process $(83.33 \%)$ and too much fluctuation in prices $(80.00 \%$ ). The problems related to processing expressed by onion growers 80.00 per cent of the respondents reported the problem of technical manpower, higher charges of power and fuels $(73.33 \%)$, fluctuation in raw material and procurement $(73.33 \%)$ and lack of good quality packaging material $(66.67 \%)$.

Highlights

(0 Onion is one of the important commercial vegetable crops grown in India and it also helps in doubling the farmers' income.
\end{abstract}

Keywords: Constraints, production, marketing and processing

Onion (Allium cepa L.) is one of the important commercial vegetable crops grown in India. It is widely grown in different parts of the country mainly by small and marginal farmers. It is used both in green and mature stage for salad and spice in a variety of flavored dishes and soups. It is very important in cookery; hence it is called the "Queen of kitchen" by Germans. It has very good medicinal value. The perpetual demand of onions within the country and for the export has made it essential to supply onions round the year either from fresh harvest or from stocks (Kumar et al. 2017).
During the year 2017-18, India occupies an area of 1285.00 thousand hectare with production of 23262.31 thousand tonnes. Maximum onion production takes place in Maharashtra (8854.09 thousand tonnes) followed by Madhya Pradesh (3701.01 thousand tonnes), Karnataka (2986.59 thousand tonnes), Bihar (1240.59.00 thousand

\footnotetext{
How to cite this article: Kumar, R., Bishnoi, D.K., Sumit and Singh, A. (2020). Constraints in Production, Marketing and Processing of Onion (Allium Cepa L.) in Nuh District of Haryana. Economic Affairs, 65(4): 653-657.

Source of Support: None; Conflict of Interest: None 
tonnes), Rajasthan (996.73 thousand tonnes), Andhra Pradesh (915.73 thousand tonnes), Haryana (701.50 thousand tonnes), West Bengal (633.50 thousand tonnes), Gujarat (546.20 thousand tonnes). The area, production and productivity of onion in Haryana were 29.93 thousand hectare, 701.50 thousand tonnes and 23.44 tonnes per hectare respectively during the year 2017-18. (National horticultural research and development foundation, 2018). In Haryana, onion has got a prominent place and holds the second position among the other vegetable crops after potato with respect to area under different vegetables.

Marketing of vegetables require more attention as compared to food grains due to their perishable in nature. Among the vegetables, onion has the advantage of being less perishable and enters into the marketing channels for inter-state and foreign trade, to a considerable extent because of added advantage that it can stand rough handling and long distance shipment. It can be stored after harvest for a considerable period by ordinary method even under unfavorable weather conditions and can be disposed off in later period in the market when the prices are favorable to the producers. It has a longer span of time for its disposal in the market as compared to other vegetables. Thus, there are huge scopes to increase area and production of this crop by providing better marketing facilities as well as high yielding varieties, modern agricultural practices to the onion growers (Kumar et al. 2016).

Profitability of onion crop not only depends upon efficient marketing but also on the modern farming practices. The various marketing intermediaries such as trader, wholesaler-cum-commission agent and retailer are involved in marketing channel of onion. Its price varies greatly from season to season because of its semi-perishable nature and immediate post-harvest sales by the growers due to financial obligation, lack of storage facilities, spoilage and other expenses incurred during storage, seasonal glut which leads the distress sales of onion. The fluctuation in prices are generated by speculative activities of intermediaries, sharp increase in the price after the bulk of produce has moved up into the whole sale market channels serving neither the interests of the producers of the ultimate consumers. Keeping in view all the above stated facts, the present study was undertaken in Nuh district of Haryana state.

\section{MATERIALS AND METHODS}

The present study was conducted in Nuh district of Haryana on the basis of highest production of onion in this district. Further block named Tauru was selected randomly a total of thirty onion farmers from various villages in this block were selected for the study. The primary data for the agriculture year 2017-18 were collected by personal interviews of the selected farmers with the help of specially designed schedule. The information about the problems faced by the onion growers were ascertained from the selected respondents as well as from selected intermediaries on various aspects of onion marketing. The information regarding problem faced by the producer in production and processing of onion were also collected from the selected respondents. For the analysis of data the descriptive statistics was used i.e. percentage.

\section{RESULTS AND DISCUSSION}

\section{Production problems expressed by onion growers}

The major problems experienced by the farmer in the production of onion are presented in Table 1. Here, it is concluded that 93.33 per cent of the respondents were reported high cost of pesticide, lack of knowledge of recommended fertilizer doses $(86.67 \%)$, high cost of fertilizer $(83.33 \%)$, lack of knowledge about the control measures for various pests and diseases $(83.33 \%)$, difficulty in identifying the pests and diseases $(80.00 \%)$, lack of knowledge about seed/seedling treatment $(76.67 \%)$, high cost of seed $(76.67 \%)$, costly storage facilities $(76.67 \%)$, lack of the knowledge about improved varieties, their seed/planting materials $(70.00 \%)$, water shortage in summer $(70.00 \%)$, inadequate irrigation facilities $(63.33 \%)$, time consuming and labour intensive manual weeding $(60.00 \%)$ and labour problem during harvesting $(56.67 \%)$. These results coincide with the study of Maru and Gibramu (2014) and Singh et al. (2020) reported the major constraints of onion production.

\section{Marketing problems expressed by onion growers:}

Marketing problems in onion are presented in table 2. The results of the study revealed that 83.33 per cent of the respondents experienced high cost of 
Table 1: Production constraints expressed by onion growers

\begin{tabular}{llll}
\hline S1. & \multirow{2}{*}{ Constraints } & \multicolumn{2}{c}{ Respondents (N=30) } \\
\cline { 3 - 4 } No. & Frequency & Percentage \\
\hline 1 & High cost of pesticides & 28 & 93.33 \\
2 & Lack of knowledge of recommended fertilizer doses & 26 & 86.67 \\
3 & High cost of fertilizer & 25 & 83.33 \\
4 & Lack of knowledge about the control measures for various pests and diseases & 25 & 83.33 \\
5 & Difficulty in identifying the pests and diseases & 24 & 80.00 \\
6 & Lack of knowledge about seed/seedling treatment & 23 & 76.67 \\
7 & High cost of seed & 23 & 76.67 \\
8 & Costly storage facilities & 23 & 76.67 \\
9 & Lack of the knowledge about improved varieties, their seed/planting materials & 21 & 70.00 \\
10 & Water shortage in summer & 21 & 70.00 \\
11 & Inadequate irrigation facilities & 19 & 63.33 \\
12 & Manual weeding is time consuming and labour intensive & 18 & 60.00 \\
13 & Labour problem during harvesting & 17 & 56.67 \\
14 & Lack of knowledge about improved storage structure & 16 & 53.33 \\
15 & Labour problem for weeding & 9 & 30.00 \\
16 & Poor quality of seed & 8 & 26.67 \\
17 & Lack of knowledge about improved method of harvesting & 6 & 20.00 \\
18 & Non availability of seed and planting materials in time & 5 & 16.67 \\
19 & Non availability of fertilizer in time & 4 & 13.33 \\
20 & Lack of knowledge about grading & 4 & 13.33 \\
\hline
\end{tabular}

Table 2: Marketing problems expressed by onion growers

\begin{tabular}{|c|c|c|c|}
\hline \multirow{2}{*}{$\begin{array}{l}\text { Sl. } \\
\text { No. }\end{array}$} & \multirow{2}{*}{ Problems } & \multicolumn{2}{|c|}{ Respondents (N=30) } \\
\hline & & Frequency & Percentage \\
\hline 1 & High cost of transportation & 25 & 83.33 \\
\hline 2 & Absence of minimum support prices & 25 & 83.33 \\
\hline 3 & Existence of large number of intermediaries in marketing process & 25 & 83.33 \\
\hline 4 & Too much fluctuation in prices & 24 & 80.00 \\
\hline 5 & $\begin{array}{l}\text { Lengthy procedure for getting credit from government institutions for marketing } \\
\text { purpose }\end{array}$ & 21 & 70.00 \\
\hline 6 & Inadequate of appropriate credit facilities & 21 & 70.00 \\
\hline 7 & Lack of market information & 17 & 56.67 \\
\hline 8 & Unorganized marketing system & 14 & 46.67 \\
\hline 9 & Long distance from the production point to market & 13 & 43.33 \\
\hline 10 & Commission agents not maintaining the proper records of sale and rate & 12 & 40.00 \\
\hline 11 & Lack of infrastructure facility & 11 & 36.67 \\
\hline 12 & Open auction sale fetches low price for produce & 9 & 30.00 \\
\hline 13 & Heavy losses in the market & 7 & 23.33 \\
\hline 14 & Lack of suitable packaging material & 6 & 20.00 \\
\hline
\end{tabular}

transportation, absence of minimum support prices (83.33\%), existence of large number of intermediaries in marketing process $(83.33 \%)$, too much fluctuation in prices $(80.00 \%)$, lengthy procedure for getting credit from government institutions for marketing purpose $(70.00 \%)$, inadequate of appropriate credit facilities $(70.00 \%)$, lack of market information (56.67\%), unorganized marketing system (46.67\%) and long distance from the production point to market $(43.33 \%)$ as major problems in marketing of onion. Similar constraints were also found by Khunt et al. (2008), Bhat et al. (2015) and Kumar et al. (2017) in their respective studies.

\section{Processing problems expressed by onion growers}

The problems related to processing expressed by onion growers are given in Table 3 which revealed that 80.00 per cent of the respondents faced the problem of technical manpower, higher charges 
Table 3: Processing problems expressed by onion growers

\begin{tabular}{llll}
\hline \multirow{2}{*}{ S1. No. } & \multirow{2}{*}{ Problems } & \multicolumn{2}{c}{ Respondents (N=30) } \\
\cline { 3 - 4 } & Frequency & Percentage \\
\hline 1 & Lack of technical manpower & 24 & 80.00 \\
2 & Higher rate of charges power and fuels & 22 & 73.33 \\
3 & Fluctuation in raw material and procurement & 22 & 73.33 \\
4 & Lack of good quality packaging material & 20 & 66.67 \\
5 & Shortage of electricity power for processing & 19 & 63.33 \\
6 & Problems in the arrangement of finance & 19 & 63.33 \\
7 & Constraints in marketing of processed product & 19 & 63.33 \\
8 & Constraints regarding location of site & 17 & 56.67 \\
9 & Lack of processing unit & 13 & 43.33 \\
10 & Problems in repair and maintenance of processing machinery & 13 & 43.33 \\
11 & Lack of suitable variety for processing & 9 & 30.00 \\
\hline
\end{tabular}

of power and fuels (73.33\%), fluctuation in raw material and procurement $(73.33 \%)$, lack of good quality packaging material $(66.67 \%)$, shortage of electricity power for processing (63.33\%), problems in the arrangement of finance $(63.33 \%)$, constraints in marketing of processed product $(63.33 \%)$, constraints regarding location of site $(56.67 \%)$ and lack of processing unit $(43.33 \%)$ were the major constraints that limit the processing of onion. Similar constraints were also found by Kumari (2017) that 90 per cent of farmers were facing the problems of dissatisfaction from price of fruits and inadequate knowledge of market information system and major constraints identified for vegetable were unavailability of cold storage facility, lack of processing plant in the state etc. Whereas un-availability of input at right time and right prices were highly significant constraints for production of these crops in the state.

\section{CONCLUSION}

Onion (Allium cepa L.) is one of the important commercial vegetable crops grown in India. The present study was conducted in Nuh district of Haryana on the basis of highest production of onion. The major problems faced by the onion farmers in production were high cost of pesticide, lack of knowledge of recommended fertilizer doses, high cost of fertilizer, lack of knowledge about the control measures for various pests and diseases, difficulty in identifying the pests and diseases, lack of knowledge about seed/seedling treatment, high cost of transportation, absence of minimum support prices, existence of large number of intermediaries in marketing process, too much fluctuation in prices, problem of technical manpower, higher rate of charges power and fuels, fluctuation in raw material and procurement and lack of good quality packaging material.

\section{Suggestions}

- Adequate scientific storage facilities should be provided to the producer so as to spread the sale throughout the year with minimum quantitative and qualitative losses.

- Producers should be provided credit facilities against the produce stored to meet their immediate financial commitments.

- Co-operatives need to be encouraged to play an important role in the marketing of onion especially for the small farmers who have poor retention capacity and should be provide adequate finance to construct storage.

- Evolution of new varieties suitable for different growing periods with longer keeping quality. This will reduce the seasonality characteristics of arrivals and prices.

- The government should make adequate arrangements for timely supply of quality seeds and other inputs at reasonable prices to the onion growers so as to increase productivity of onion crop.

- The government should fix the procurement price for the onion in advance so that producers can get reasonable price. 
- Time to time trainings on improved storage techniques may be provided to onion growers.

\section{ACKNOWLEDGEMENTS}

Authors wish to acknowledge Chaudhary Charan Singh Haryana Agricultural University and all the farmers who participated in the study and made the study successful.

\section{REFERENCES}

Annonymous. 2018. National Horticultural Research and Development Foundation, New Delhi (www.nhrdf.org.).

Khunt, K.A., Gajipara, H.M., Gadhvi, B.K. and Vekariya, S.B. 2001. Economics of production and marketing of pomegranate. Ind. J. Agril. Mar., 17(1): 100-107.

Kumar, R., Bishnoi, D.K., Rathi, A. and Prakash, S. 2016. Marketing and price behaviors of onion in Haryana. Ind. J. Eco. Dev., 12(1a): 7-11.
Kumar, R., Rathee, A.K., Dalip, D.K. and Sumit. 2017. Trends and constraints in onion production in Haryana. Ind. J. Eco. Dev., 13(2a): 309-313.

Kumari, M. 2017. Estimation of demand supply gap and major constraints in production and marketing of major fruits and vegetables in Bihar, India. Int. J. Cur. Microb. Appl. Sci., 6(6): 2662-2672.

Maru, A.B. and Gibramu, A.B. 2014. Constraints of onion (Alluim cepa.var.cepa L.) yield production and food preference to shallot (Alluim cepa.var. aggregatum) in the case of Bibugn Woreda, Amhara Regional State, Ethiopia. Food Sci. and Qua. Mant., 32(2): 41-46.

Singh, A., Bishnoi, D.K., Kumar, N. and Kumar, R. 2020. Constraints faced in adoption of establishment techniques of wheat in Karnal and Kaithal districts of Haryana. Economic Affairs, 65(2): 179-181.

Bhat, A., Kachroo, J., Sharma, M. and Peshin, R. 2015. Constraints in production and marketing of citrus fruit in Jammu region of J\&K State. Economic Affairs, 60(2): 331-337. 
